THE CHANKAS AND THE PRIEST 


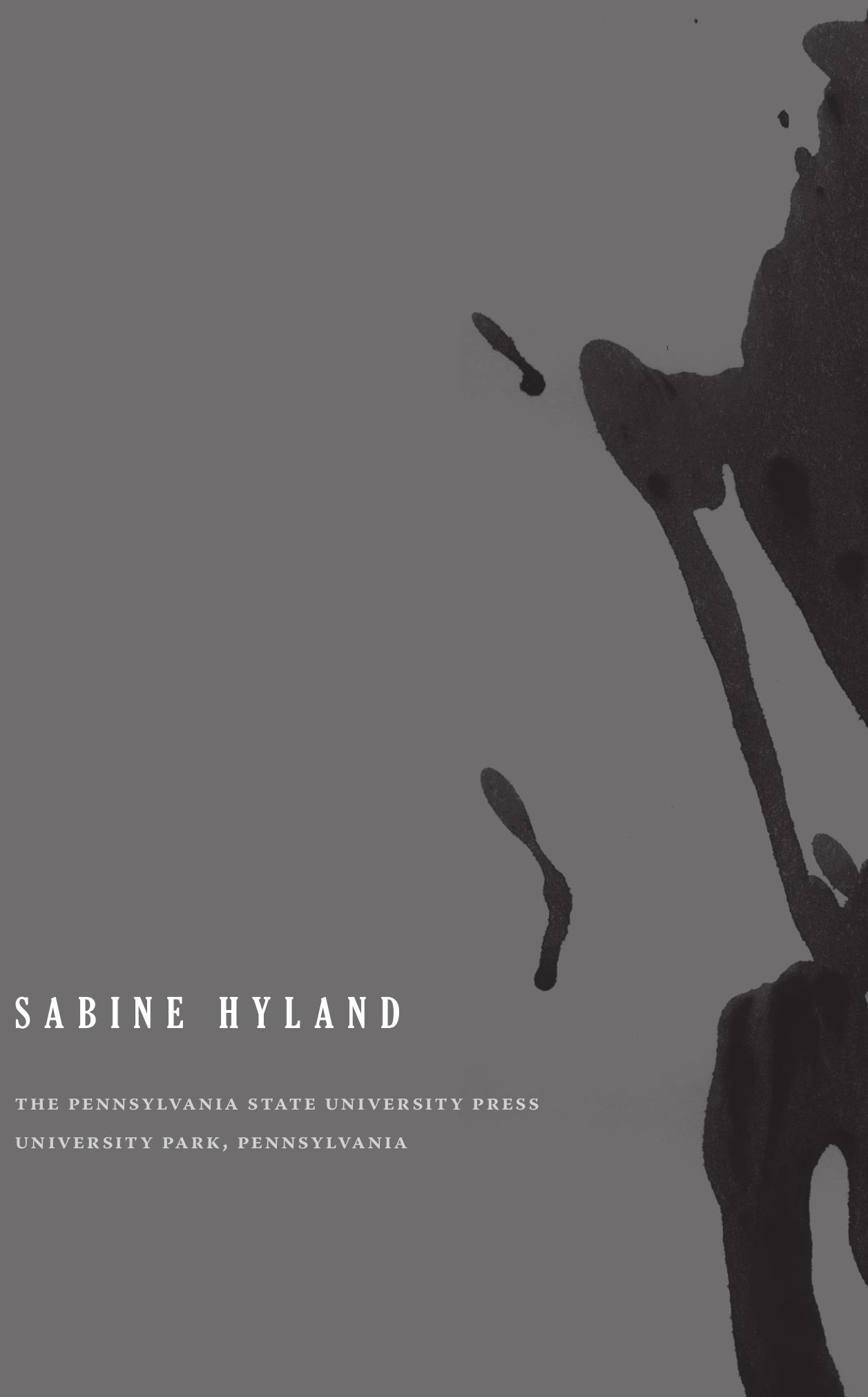




\section{THE CHANKAS}

AND THE PRIEST

A Tale of Murder and Exile in Highland Peru 
Names: Hyland, Sabine, 1964- , author.

Title: The Chankas and the priest : a tale of murder and exile in highland Peru / Sabine Hyland.

Description: University Park, Pennsylvania : The Pennsylvania State University Press, [2016] | Includes bibliographical references and index.

Summary: "Presents the story of the Chanka people of Peru, from the fifteenth to the eighteenth centuries, told through a narrative of the crimes committed by a priest, Juan Bautista de Albadán, in the early 16oos"Provided by publisher.

Identifiers: LCCN 2015044963 | ISBN 9780271071220 (cloth : alk. paper)

Subjects: LCSH: Chanca Indians-History. | Bautista de Albadâan, Juan, 1562-1611. | Chanca IndiansCrimes against-Peru-Pampachiri-History. | Peru-History-Conquest, 1522-1548. | PeruHistory-1548-1820. | Pampachiri (Peru)-History.

Classification: LCC F3430.1.C4 H95 2016 | DDC 985/.03dc23

LC record available at http://lccn.loc.gov/2015044963

Copyright $\odot 2016$

The Pennsylvania State University

All rights reserved

Printed in the United States of America

Published by The Pennsylvania State University Press,

University Park, PA 16802-1003

The Pennsylvania State University Press is a member of the Association of American University Presses.

It is the policy of The Pennsylvania State University Press to use acid-free paper. Publications on uncoated stock satisfy the minimum requirements of American National Standard for Information Sciences-Permanence of Paper for Printed Library Material, ANSI Z39.48-1992.

This book is printed on paper that contains $30 \%$ post-consumer waste. 
This book is dedicated

with gratitude to my

teacher and mentor

Richard L. Burger. 
